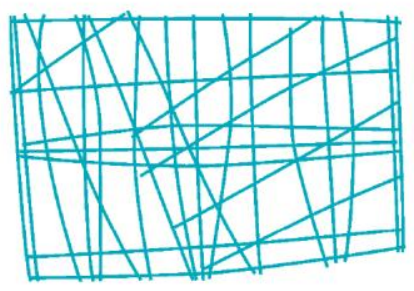

NEREUS

Núcleo de Economia Regional e Urbana

da Universidade de São Paulo

The University of São Paulo

Regional and Urban Economics Lab

THE REGIONAL ECONOMIC STRUCTURE OF BRAZIL IN 1959: AN OVERVIEW BASED ON AN INTER-STATE INPUTOUTPUT SYSTEM

Gustavo Barros

Joaquim José Martins Guilhoto

TD Nereus 13-2011

São Paulo

2011 


\title{
The Regional Economic Structure of Brazil in 1959: An Overview Based on an Inter-State Input-Output System ${ }^{1}$
}

\author{
Gustavo Barros and Joaquim José Martins Guilhoto
}

\begin{abstract}
This paper aims at describing the regional configuration of 1959 Brazil's productive structure through the estimation of an Inter-State Input-Output system. The estimated matrix is the oldest of this kind for Brazil. It can, hence, be an important tool for the study of the regional productive structure at an historical moment in which the regional question appeared as a central national issue. In this paper we describe estimation procedures and sources of data, and present some general characterization of the regional structure of the economy in 1959 through selected structural indicators.
\end{abstract}

Resumo. Este trabalho tem como objetivo descrever a configuração regional da estrutura produtiva da economia do Brasil em 1959, através da estimação de um sistema de InsumoProduto Interestadual. A matriz estimada é a mais antiga desse tipo existente para o Brasil. Pode, portanto, ser uma ferramenta importante para o estudo da estrutura produtiva regional em um momento histórico em que a questão regional aparece como uma questão central no país. Neste trabalho, descrevemos os procedimentos de estimação, as fontes de dados, e apresentamos uma caracterização geral da estrutura produtiva regional da economia brasileira em 1959 usando alguns indicadores estruturais selecionados.

\section{Introduction}

This paper aims at describing the regional configuration of 1959 Brazil's productive structure through the estimation of an Inter-State Input-Output Matrix. The estimation was made based on Rijckeghem's national matrix for $1959^{2}$ and additional data obtained from several sources, using inter-industry and locational quotients.

Rijckeghem's matrix for 1959 is the oldest input-output matrix available for Brazil, and our estimation is thus the oldest inter-state matrix for the country. It can, hence, be an important tool for the study of the regional productive structure at an historical moment in which the regional question appeared as a central national issue.

\footnotetext{
${ }^{1}$ The authors would like to thank the Biblioteca da Unidade de São Paulo do Instituto Brasileiro de Geografia e Estatística, and its solicitous librarians, for providing essential material for this research. We also thank André Luís Squarize Chagas and Esther Dweck for valuable comments and bibliographical references.

${ }^{2}$ Willy van Rijckeghem; with the collaboration of Sérgio Alípio de Oliveira Camargo, 'Tabela de insumoproduto, Brasil - 1959', Texto para discussão do IPEA, (Sept. 1967).
} 
In the next part of this paper we describe estimation procedures and sources of data. And in the following one we present a general overview of the regional structure of the Brazilian economy in 1959 through selected structural indicators of the estimated matrix.

\section{Sources of Data and Estimation Procedure}

Considering that a relevant objective of this paper is to make public and available the estimated matrix, it is important for us to describe in some detail the estimation procedures and sources of data, so that other researchers eventually using our estimation for their own analyses will be able to assess by themselves its limitations and possibilities.

Our starting point has been Rijckeghem's national Input-Output table for $1959 .^{3} \mathrm{He}$ considered the estimation of the national matrix he published in 1967 as 'preliminary' due to the lack of part of the results of the 1960 Censuses (base year 1959) which were at that moment yet to be published. He had access to the results of the Industrial and of the Commerce and Service Censuses. The Agricultural and the Demographical Censuses were unpublished when he prepared his estimates. Besides, none of the censuses included 'transportation and communication, construction, electric energy, water and sanitary services, financial services, medical services, domestic services, and education'. To supply for this lack of direct information, affecting mainly the non-industrial sectors, Rijckeghem made use of secondary statistical data. We are, however, unaware of any later revision of this 'preliminary' estimate. Additionally, Rijckeghem resorted to three 'fictitious' sectors namely Wastes, Fuels, and Packaging - in order to 'profit from the way the cost structure of industrial enterprises were presented', making the matrix sectoral structure less than typical. ${ }^{4}$

\footnotetext{
${ }^{3}$ Willy van Rijckeghem, 'Tabela de insumo-produto'; 'An Intersectoral Consistency Model for Economic Planning in Brazil', in Howard S. Ellis (ed.), The Economy of Brazil (Berkeley and Los Angeles, CA: University of California Press, 1969), pp. 376-401. For a contemporary comment on the Rijckeghem's inputoutput table see J. T. Winpenny, 'Industrialization in Brazil', Journal of Latin American Studies, Vol. 2 , No. 2 (Nov., 1970), pp. 199-208.

${ }^{4}$ A reasonably detailed account of the procedures he adopted can be found in Rijckeghem, 'Tabela de insumoproduto', from where this paragraph's quotes were taken (pp. 1-4). The table, but not the description of procedures, was published in Rijckeghem, 'An Intersectoral Consistency Model'.
} 
These shortcomings of Rijckeghem's 1967 estimate - many of which he recognizes himself are inevitably carried over to our own estimate of the Inter-State matrix once it is based on his national matrix. Still, the best information which he had available, and also the best information which we were able to collect for our regional disaggregation, was that pertaining to the industrial sectors and their interrelations which constitute the main focus of many input-output analyses. Moreover, of the 32 sectors of his Input-Output table, 22 were covered by the Industrial Census, thus providing a reasonably sound basis for a set of analyses of some relevant historical questions traditionally addressed regarding this period.

Starting then from Rijckeghem's table, adding new information and some hypotheses, we performed two disaggregating steps: $1^{\text {st }}$ ) the original metallurgical sector has been divided into two subsectors in the national matrix, one of iron and steel metallurgy and a second gathering other metallurgical production, in order to obtain more detail about this specific sector, resulting thus in a 33 sector national matrix; $2^{\text {nd }}$ ) this 33 sector national matrix was then disaggregated into an Inter-State matrix with 25 states.

In order to disaggregate the metallurgical sector of Rijckeghem's original matrix into a 'Metallurgical (iron and steel)' and 'Metallurgical (other)' sectors we used coefficients for these sectors from a 1970 national Input-Output matrix for Brazil. The precise hypotheses involved can be stated as: a) the proportion of internal production, destined to each of the other sectors and to final demand, of the 'metallurgical (iron and steel)' sector relative to the sector of 'metallurgical (other)' within the total metallurgical sector is the same in 1959 as in 1970 ; b) the proportion of input consumption, provided by each of the other sectors and by value added entries, of the 'metallurgical (iron and steel)' sector relative to the sector of 'metallurgical (other)' within the total metallurgical sector is the same in 1959 as in 1970 . We could thus ensure that the 33 sector matrix can be reaggregated back into the original 32 sector matrix exactly.

The use of the 1970 matrix's coefficients was the best information available for the purpose at hand. The Censuses of 1960 as they were published do not allow to recover the necessary information, given the metallurgical sector was reported aggregated in the Industrial Census. 
Moreover, we judged the information of the 1970 matrix of better quality - including accuracy and level of detail - relative to other pertinent secondary sources we were able to find for 1959. It is true that both the iron and steel sector and the other metallurgical sector changed significantly from 1959 to 1970 . The soundness of our hypothesis does not rely, however, on their immutability but on a certain degree of similarity in the development of each subsector of the metallurgical total, which is much more tenable. We can, hence, expect our hypothesis to produce a reasonable approximation - in any case, as good as we were able to achieve - of the desired ideal of direct information.

The estimation of the Inter-State matrix, based on the national matrix we just described, required much additional data, which were found and provided in various degrees of quality. The following sources were used, in this order of priority: $1^{\text {st }}$ ) the censuses of 1960 , especially the Industrial and the Commerce and Services Censuses; $2^{\text {nd }}$ ) the National Accounts or the Statistical Year-Book of $1961 ; 3^{\text {rd }}$ ) estimates based on proxies from the Censuses, the Statistical Year-Book or the National Accounts. ${ }^{5}$

Basically, what was needed for the estimation was information on: a) the distribution by state of the (origin of) production for each sector $(1)$; b) the distribution by state of the (origin of) value added, including gross returns to capital (2) and wages, salaries, and social security (3); c) the distribution by state of the (destiny of) final demand, including households consumption (4), government consumption (5), investment (6), exports (7), and imports (8).

This information was compiled from the above mentioned sources, and organized in a set of eight matrices in the form Sector X State. A minute description of data sources and

\footnotetext{
${ }^{5}$ Brasil, VII Recenseamento Geral do Brasil, Série Nacional, vol. 1: Censo Demográfico de 1960 ([Rio de Janeiro]: Fundação IBGE, Departamento de Estatísticas da População, n.d.); vol. 2: Censo Agrícola de 1960, $1^{a}$ Parte (Rio de Janeiro: IBGE - Serviço Nacional de Recenseamento, Sept. 1967); vol. 3: Censo Industrial de 1960 (Rio de Janeiro: IBGE - Serviço Nacional de Recenseamento, March 1967); vol. 4: Censos Comercial e dos Serviços de 1960 (Rio de Janeiro, IBGE - Serviço Nacional de Recenseamento, June 1967); [Brasil], VII Recenseamento Geral do Brasil, Série Especial, vol. 5: Censo Industrial de 1960: Matérias-primas e produtos (Rio de Janeiro: Fundação IBGE - Serviço Nacional de Recenseamento, Sept. 1968); Fundação Getúlio Vargas (FGV), 'Contas Nacionais', Revista Brasileira de Economia (Rio de Janeiro: FGV, Ano 15, No 1, March 1961); Instituto Brasileiro de Geografia e Estatística (IBGE), Conselho Nacional de Estatística. Anuário Estatístico do Brasil - 1961, Ano XXII (Rio de Janeiro: IBGE, Dec. 1961).
} 
hypotheses for the necessary estimates is provided in the

Appendix. Still, some general comments about it are due here. It is important to note that the regional information on the 23 industrial sectors is judged to be of very good quality. It was almost entirely taken from the Industrial Census - the distribution of production by state was entirely so, value added was mostly so, final demand was not. This is not only the same source as that of Rijckeghem's national matrix, but is also the best information source we could desire. The source used for the primary sectors (1 and 2) was the same Rijckeghem used, the national accounts, hence a good degree of consistency with the national matrix was assured. The distribution of production by state of the remaining sectors relied, partly or totally, on estimates. In several of them - electric energy, services, residuals, fuels, packaging, and transportation - a specific kind of hypothesis was necessary, which deserves mention. The estimates of origin of production by state of each of theses sectors were made based on information on expenditures by state in these sectors. Formally, this is an accounting mistake. Here it can be thought of as implying an implicit hypothesis, namely, we are supposing these sectors to exhibit a high degree of non-tradability between states. In other words, our estimates will be the better the less tradable these sectors are. This hypothesis is reasonably good for most of the concerned sectors, and not that good for some of them fuels and electric energy being the worst cases, we believe. Hence, due care should be taken in analyses of regional emphasis for these sectors based in our estimates. The procedures adopted imply an underestimation of the regional interaction for these sectors. Origin of value added and destiny of final demand by state were also estimated. Estimates of value added for the industrial sectors were based on consistent primary data from the Industrial Census. Value added for the remaining sectors and final demand by state were estimated based on secondary data. The quality of the results along the estimated inter-state matrix should vary according to these different types of sources of information we used.

With this set of eight matrices in the form 33 Sectors X 25 States and the national matrix with 33 sectors in hand, we then proceeded the estimation of the inter-state matrix. Regional coefficients $\left(a_{i j}^{R R}\right)$ were estimated as proportions of the correspondent national technical coefficients $-a_{i j}^{N}=z_{i j}^{N} / X_{j}^{N}$, were $z_{i j}^{N}$ is the (national) flow of input from sector $i$ used by 
sector $j$ to produce its total (national) output $X_{j}^{N}-$ calculated from the national matrix. For this purpose we used cross-industry quotients for the intermediary consumption part of the matrix and simple location quotients for most of the final demand part of the matrix. ${ }^{6}$

We have adopted cross-industry quotients to estimate the intermediary consumption part of the matrix because it affords greater flexibility once it allows us to calculate a different coefficient for each cell of the regional matrix. Cross-industry quotients were thus defined:

$$
C I Q_{i j}^{R}=\left[\frac{X_{i}^{R} / X_{i}^{N}}{X_{j}^{R} / X_{j}^{N}}\right],
$$

were $X_{i}^{R}$ and $X_{j}^{R}$ are respectively the output of sectors $i$ and $j$ in region $R$ (states), and $X_{i}^{N}$ and $X_{j}^{N}$ the outputs of the same sectors at the national level. The (intra)regional coefficients were then estimated according to the cross-industry quotients:

$$
a_{i j}^{R R}= \begin{cases}a_{i j}^{N}\left(C I Q_{i j}^{R}\right) & \text { if } C I Q_{i j}^{R}<1 \\ a_{i j}^{N} & \text { if } C I Q_{i j}^{R} \geq 1\end{cases}
$$

The cross-industry quotient measures the region's share in the national production of the input sector $(i)$ relative to the region's share in the national production of the output sector $(j)$. The idea behind this procedure is that if the region's share of the input sector is larger than the region's share of the output sector - that is, if $C I Q_{i j}^{R} \geq 1-$ then all the needs of input $i$ for the production of output $j$ in region $R$ can be supplied from within the region. Conversely, if $C I Q_{i j}^{R}<1$, a part of the input $i$ for the production of output $j$ in region $R$ will have to be 'imported' from other regions. The interregional coefficients were then estimated on the basis of market shares of the remaining regions in the input sector:

\footnotetext{
${ }^{6}$ For definitions and discussion on different alternatives of regionalizing coefficients see Ronald E. Miller and Peter D. Blair, Input-Output analysis: Foundations and extensions, (Englewood Cliffs, NJ: Prentice-Hall, 1985), pp. 295-302.
} 
$a_{i j}^{L R}=\left(a_{i j}^{N}-a_{i j}^{R R}\right) \cdot \frac{X_{i}^{L}}{X_{i}^{N}-X_{i}^{R}}$,

where $X_{i}^{L}$ is the output of sector $i$ in region $L$, and the remaining variables are defined as above. An intermediate consumption matrix in the form Sector X State was calculated from the basic set of Sector X State matrices (intermediate consumption = output - gross returns to capital - salaries, wages and social security). This matrix was then used to calculate an interstate intermediate consumption flow matrix distributing each of the Sector X State matrix's cells proportionately to the corresponding column of regional coefficients.

The estimation of the regional distribution of household consumption, government consumption and investment, in the final demand part of the matrix, was made with simple location quotients defined as:

$$
L Q_{i}^{R}=\left[\frac{X_{i}^{R} / X^{R}}{X_{i}^{N} / X^{N}}\right],
$$

were $X^{R}$ is the total production of region $R$ and $X^{N}$ is the total national production, and the remaining variables are defined as above. The estimation of intra- and interregional coefficients was then made for these final demand items with these simple location quotients exactly as it was done for the intermediary consumption with the cross-industry quotients, and described above.

Regarding imports and exports, we assumed that they were made by each state only directly with the foreign. This assumption however, and the use of data on imports and exports from ports and airports to distribute respectively imports and exports through the states (see

Appendix), do imply an underestimate of the international trade of the Brazilian 
mediterranean states.

For the value added part of the matrix we assumed that value added items could only be supplied locally. These assumptions, in turn, implied that the regional distribution of imports, exports, and value added items could be determined directly from the corresponding Sector X State matrices described above.

At this point, we have thus a first complete estimate of the inter-state input-output table, but which is not yet fully consistent. ${ }^{7}$ Consistency adjustments were then made, in handicraft fashion, bearing two general criteria in mind: i) attempt to preserve the estimated technological relations; ii) attempt to deviate as little as possible from the original national matrix when reaggregating back the inter-state estimated matrix. According to these criteria, we imposed the consistency adjustments on the final demand items allowing for only moderate deviations relative to the original national matrix, when reaggregated, and were able to obtain what we judged a reasonable result without further intervention. We were thus able to assure no distortion of the inter-sectorial technical relations estimated from the original sources of data and that the estimated inter-state matrix aggregates back into the national matrix exactly throughout the intermediate consumption and value added parts of the matrix. However, this was done at the cost of a poorer estimation of final demand items. It is important to mention, though, that these adjustments are, even if flimsy, not quite arbitrary, once the consistency of the matrix does carry information regarding its internal structure. The estimated inter-state input-output matrix is now consistent and can be used for the study of the regional and productive economic structures for Brazil 1959.

\section{Regional Economic Structure of Brazil in 1959}

Having described the data, procedures and hypothesis used to estimate the inter-state matrix for Brazil 1959, we now provide a general characterization of the Brazilian economic

\footnotetext{
${ }^{7}$ In the sense that the sums over the columns of the matrix are not equal to the sums over the corresponding lines of the matrix. Given the procedures employed to obtain this estimate, there was no reason to expect accounting consistency at this point.
} 
structure as depicted in the estimated matrix through selected indicators. The intention is to supply an overview of the regional economic structure of Brazil at that moment by means of the identification of key sectors and regions. For the purpose, we have chosen forward and backward cumulative linkages (Rasmussen-Hirschman type), output multipliers, and forward, backward and total pure linkages as indicators. ${ }^{8}$ In general, the chosen indicators have been calculated and ranked for each sector within each state relative to the national economy. Rasmussen-Hirschman linkages and output multipliers were also calculated for whole regions and whole sectors relative to the national economy.

In order to set notation and terminology we initially provide some definitions. Given a general set of monetary terms input-output relations:

\begin{tabular}{|l|l|l|}
\hline$Z$ & $Y$ & $X$ \\
\hline$W^{\prime}$ & - & $W^{\prime} \cdot e$ \\
\hline$X^{\prime}$ & $e^{\prime} . Y$ & \\
\hline
\end{tabular}

where (i) $Z$ is a (N.R x N.R) matrix of intermediate flows; (ii) $Y$ is a (N.R $\times 1$ ) vector of final demand comprising (aggregating), in our case, household consumption, government consumption, investment, exports and imports; (iii) $X$ is a (N.R x 1) vector of total output; (iv) $W$ is a (N.R x 1) vector of value added comprising (aggregating), in our case, gross returns to capital and wages, salaries and social security; (v) $e$ is a summation vector, a (N.R $\mathrm{x} 1$ ) vector of ones, that is, $(1,1, \ldots, 1)^{\prime} ;$ ( vi) $\mathrm{N}$ is the number of sectors; (vii) $\mathrm{R}$ is the number of states.

Given this set of input-output relations, we can define both a demand-driven (Leontief) model

\footnotetext{
${ }^{8}$ For definitions and discussion on the subject, on which we rely upon, see Erik Dietzenbacher, 'In Vindication of the Ghosh Model: A Reinterpretation as a Price Model', Journal of Regional Science, Vol. 37, No. 4 (1997), pp. 629-651; Joaquim J. M. Guilhoto, Michael Sonis and Geoffrey J. D. Hewings, 'Linkages and Multipliers in a Multiregional Framework: Integration of Alternative Approaches', Australasian Journal of Regional Studies, Vol. 11, No. 1, (2005), pp. 75-89; Jan Oosterhaven, Gerard J. Eding and Dirk Stelder, 'Clusters, Forward and Backward Linkages, and Bi-regional Spillovers: Policy Implications for the two Dutch Mainport Regions and the Rural North', Paper presented at the $39^{\text {th }}$ European Congress of the Regional Science Association International, (Aug. 23-27, 1999, University College Dublin); Miller and Blair, Input-Output analysis.
} 
or a supply-driven (Ghosh) model. The former can be stated as:

$A X+Y=X \quad$ or $\quad X=(I-A)^{-1} Y$

where $A \equiv Z(\hat{X})^{-1}$, being $A$ the matrix of technical input coefficients and $(I-A)^{-1}$ is the Leontief inverse.

Similarly, the supply-driven model can be stated as:

$X^{\prime} B+W^{\prime}=X^{\prime} \quad$ or $\quad X^{\prime}=W^{\prime}(I-B)^{-1}$

where $B \equiv(\hat{X})^{-1} Z$, being $B$ the matrix of technical output coefficients and $(I-B)^{-1}$ is the Ghosh inverse.

In a first approach to the structural characterization of the matrix, we used cumulative (Rasmussen-Hirschman) forward and backward linkages. As the row sums of the Leontief inverse have been criticized as indicators of forward linkages, ${ }^{9}$ we used for the purpose the row average of the Ghosh inverse relative to the average element of that matrix, that is, $\left((I-B)^{-1} e /(N . R)\right) /\left(e^{\prime}(I-B)^{-1} e /(N . R)^{2}\right)$. Therefore, forward linkages are here defined in the context of a supply-driven model (or rather a Ghosh price model), and can be interpreted as a measure of the changes in the value of output of all sectors together, given an increase in the value added of the sector in question. ${ }^{10}$

We calculated forward linkages in this fashion for each sector within each state relative to the national economy. The 25 largest linkages are presented in Table 1 below.

The results obtained point at the importance of the state of São Paulo (SP), and of basic industries sectors, such as chemical industry, transportation goods, electrical goods, and

\footnotetext{
${ }^{9}$ See Dietzenbacher, 'In Vindication of the Ghosh Model', p. 636.

${ }^{10}$ Dietzenbacher, 'In Vindication of the Ghosh Model', p. 638.
} 
metallurgy. But some traditional industries, such as food or textiles (in SP), also appear as important sectors, having highly ranked forward linkages. Also, the construction sector of four states (GB, SP, MG, GO) appear among the largest linkages. SP counted 14 of its 33 sectors within the first 25 largest forward linkages, 18 among the first 50, and 20 among the first 100. These same figures were, respectively: for Rio de Janeiro (RJ), 1, 3, and 4; for Guanabara (GB), 2, 5, and 11; for Minas Gerais (MG), 4, 6, and 6; for Rio Grande do Sul (RS), 1, 3, and 6; for Paraná (PR), 1, 4, and 6. It is interesting to notice that the sector of metallurgy of iron and steel figures twice among the largest 25, in the states of RJ and MG, but not in the state of SP (which ranks $27^{\text {th }}$ ). Furthermore, it deserves mention that the forward linkages presented a much skewed distribution, that is, a few sectors stand clearly out relative to all others. This can be perceived already from Table 1, if we remember that the average of the linkages obtained is 1 (by definition), and that the full list comprises a total of 825 sectors.

Cumulative backward Rasmussen-Hirschman were also calculated for each sector within each state relative to the national economy in traditional fashion, as the column average of the Leontief inverse relative to the average element of that matrix, that is, as $\left(e^{\prime}(I-A)^{-1} /(N . R)\right) /\left(e^{\prime}(I-A)^{-1} e /(N . R)^{2}\right)$. Some aspects of the results call the attention. The first one is the clear prevalence of the sectors of wastes, fuels, and packaging, regardless of the state, among the largest backward linkages. These sectors account for 24 of the 25 largest backward linkages, and 49 of the largest 50. These three sectors come from the original national matrix estimated by Rijckeghem, ${ }^{11}$ who call these sectors 'fictitious', as we mentioned above. These sectors are called fictitious by him because they have no value added assigned for them. The relatively very high backward linkages obtained for these sectors doubtlessly stem from this characteristic. This is, therefore, a caveat carried from the original national matrix.

\footnotetext{
${ }^{11}$ Rijckeghem, 'Tabela de insumo-produto'.
} 
Table 1. Largest Forward Linkages

\begin{tabular}{clcc}
\hline Rank & \multicolumn{1}{c}{ Sector } & State & $F L$ \\
\hline 1 & Chemical industry & SP & 15.90 \\
2 & Transportation goods & SP & 11.44 \\
3 & Food & SP & 7.37 \\
4 & Electrical goods & SP & 7.28 \\
5 & Metallurgy (iron and steel) & RJ & 6.28 \\
6 & Textiles & SP & 5.95 \\
7 & Construction & GB & 5.81 \\
8 & Construction & SP & 5.57 \\
9 & Metallurgy (other) & SP & 5.10 \\
10 & Fuels & SP & 5.07 \\
11 & Machine tools & SP & 4.70 \\
12 & Construction & MG & 4.32 \\
13 & Construction & GO & 4.23 \\
14 & Rubber & SP & 4.18 \\
15 & Food & PR & 4.05 \\
16 & Clothing & SP & 4.00 \\
17 & Chemical industry & GB & 3.77 \\
18 & Food & RS & 3.76 \\
19 & Services & RO & 3.48 \\
20 & Transportation & MG & 3.40 \\
21 & Metallurgy (iron and steel) & MG & 3.30 \\
22 & Non-metallic minerals & SP & 3.20 \\
23 & Packaging & SP & 3.17 \\
24 & Fuels & MG & 3.07 \\
25 & Transportation & SP & 3.04 \\
\hline
\end{tabular}

Source: elaborated by the authors.

The second important aspect to be noticed in the backward linkages' results is that, disregarding the fictitious sectors, the small states of the economy rather than the large ones exhibit the largest linkages, and, in several cases, in sectors which are usually characteristic of the large states. For example: paper in Mato Grosso $\left(1^{\text {st }}\right)$, Sergipe $\left(4^{\text {th }}\right)$, Espírito Santo $\left(5^{\text {th }}\right)$, Paraíba $\left(5^{\text {th }}\right)$, and Ceará $\left(9^{\text {th }}\right)$; transportation goods in Ceará $\left(10^{\text {th }}\right)$, Piauí $\left(11^{\text {th }}\right)$, and Paraíba $\left(13^{\text {th }}\right)$; electrical goods in Goiás $\left(7^{\text {th }}\right)$, and Espírito Santo $\left(21^{\text {st }}\right)$; or chemical industry in Piauí $\left(8^{\text {th }}\right)$. 
A third important aspect is that some sectors display low variability of the backward linkage along the states, particularly the non-industrial ones. Indeed, their distribution is in general much more homogeneous than the forward linkages' one. All backward linkages are within the range of 0.52 to 1.73 , without the presence of clear outliers.

These two latter aspects of the results obtained for the backward linkages can, indeed, be largely imputed to the procedures used to estimate the inter-state input-output matrix, which were described above. The low variability of the linkages for each sector along the states, where this is the case, much likely stems from our initial hypothesis of estimating the states technical coefficients as proportions of the respective national ones. We can think of this as a sector specific limitation of the sources of data used in the estimation procedures. The prominence of small states - disregarding the fictitious sectors - can also be explained by this same estimation step, but in a different sense. The cross-industry quotients used to estimate the states' technical coefficients from the national ones were calculated from market shares. This is an approximation which is more likely to fail the more diverse the technologies aggregated within each sector. Larger technological diversity within a sector is to be found in higher technology sectors, as the ones mentioned above. Therefore, an overestimation of the structural role of this kind of sector in small states is resulting from an underestimation of technological diversity within these sectors, along the different states. The fact that forward linkages are much more skewed than the backward linkages, however, is already present in the original national matrix.

Although we can understand the results obtained, they are certainly to be considered an important caveat of the estimation procedures adopted. For this reason, in the case of backward linkages, we recommend the use of pure backward linkages - presented below which take into consideration the economic size of the respective sector in evaluating its relevance, thus reducing - albeit by no means eliminating - the problems discussed here. 
Indeed, it is relevant to mention that not even the forward linkages presented above are detached from this issue, something we can see by noticing that the sector of services in Rondônia (RO) has the $19^{\text {th }}$ highest forward linkage in the economy. But it seems to us they were less affected.

Another perspective of the matrix's structure can be seized from less disaggregated backward and forward linkages for whole states and for whole sectors. These linkages we calculated by means of analogous definitions as the ones stated above. We present plots of backward vs. forward linkages in each case, in order to grasp the relevance of each state or sector through the consideration of both indicators simultaneously.

Figure 1 presents an interesting picture of the regional economic structure of Brazil 1959. The first noteworthy feature of these results is that the few states (seven) that exhibit above average forward linkages also display above average backward linkages. Another interesting characteristic of the results is that these seven key states are none less than the six economically largest states, and the eighth (SP, GB, MG, RS, PR, RJ, and PE). Moreover, almost all of these states are geographically concentrated in the Southeast and South regions (in current regional grouping, which is different from the one prevailing at the time). The case of SP is particularly impressive. Of course, the enormous share of these states in the national economy is well known. But this is indeed a remarkable feature, especially when we recall that Rasmussen-Hirschman linkages have been criticized for not taking into account the respective level of output. These results suggest, thus, a self-reinforcing character of the regional concentration of the economic structure of the country, as well as a large degree of intra-regional, and even intra-state, endogeneity of intermediate consumption. 
Figure 1. Backward vs. Forward Linkages of States

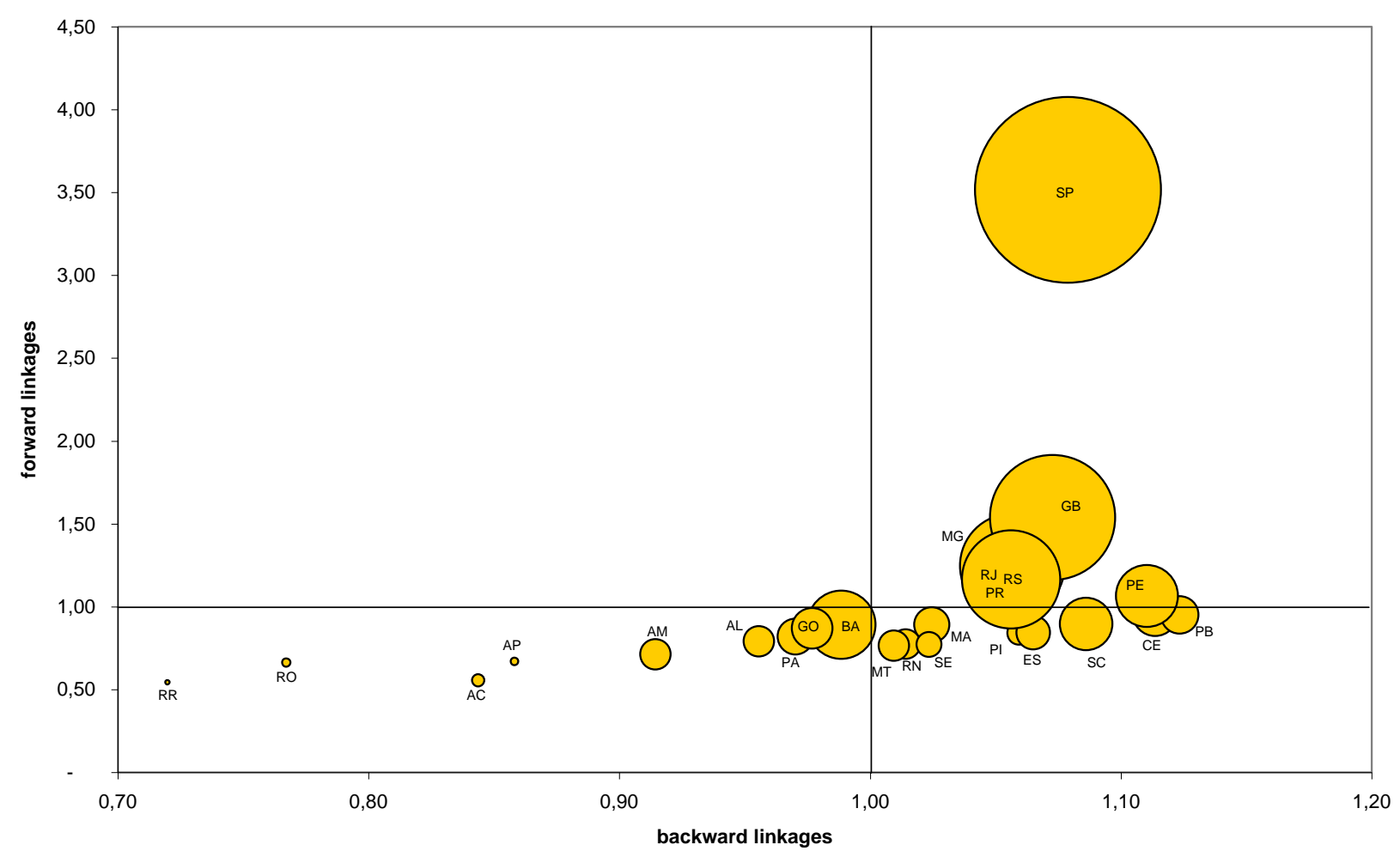

Note: Size of the bubbles represents the states' GDP.

Source: elaborated by the authors.

It is interesting to remember that 1959 is precisely the year that the Superintendência do Desenvolvimento do Nordeste (Superintendency of the Development of the Northeast, SUDENE) was created by the Brazilian government in order to promote the north-eastern region's development, directing resources to that region. ${ }^{12}$ The results here obtained point to a short term trade-off between efforts towards regional economic homogenization and national output growth.

Still another perspective to this issue can be reached by the following table, were we present (type I) output multipliers for each state, separating the effects which take place inside the

${ }^{12}$ For a discussion on Brazilian regional inequalities from a structural perspective and on Brazilian regional policy along the subsequent period see D. E. Goodman, 'The Brazilian Economic "Miracle" and Regional Policy: Some Evidence from the Urban Northeast', Journal of Latin American Studies, Volume 8, Issue 1, (May 1976), pp. 1-27. 
state from the ones which take place outside it. Total output multiplier was defined as the average of the column sums for every sector within each state, that is, as $\left(e^{\prime}(I-A)^{-1} e_{R}\right) / N$, where $e_{R}$ is a (N.R x 1) state specific summation vector with ones in the lines corresponding to state $R$, and zeros in the remaining lines, that is,

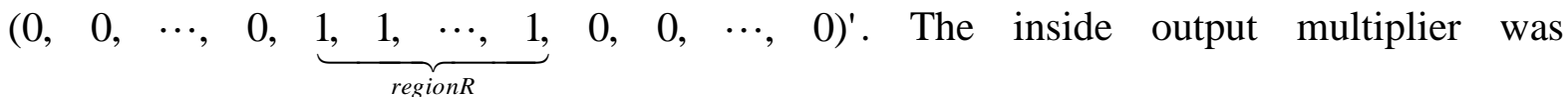
correspondingly defined as $\left(e_{R}{ }^{\prime}(I-A)^{-1} e_{R}\right) / N$, and the outside output multiplier as the difference between both.

Table 2. Total, Inside, and Outside Output Multipliers for States

\begin{tabular}{|c|c|c|c|c|}
\hline \multirow[t]{2}{*}{ Region } & \multirow[t]{2}{*}{ State } & \multicolumn{3}{|c|}{ Output Multipliers } \\
\hline & & Total & Inside & Outside \\
\hline \multirow{6}{*}{ North } & RO & 1.47 & $1.15(78 \%)$ & $0.32(22 \%)$ \\
\hline & $\mathrm{AC}$ & 1.61 & $1.22(76 \%)$ & $0.39(24 \%)$ \\
\hline & $\mathrm{AM}$ & 1.75 & $1.46(84 \%)$ & $0.29(16 \%)$ \\
\hline & $\mathrm{RR}$ & 1.38 & $1.13(82 \%)$ & $0.25(18 \%)$ \\
\hline & PA & 1.86 & $1.40(75 \%)$ & $0.46(25 \%)$ \\
\hline & AP & 1.64 & $1.23(75 \%)$ & $0.41(25 \%)$ \\
\hline \multirow{7}{*}{ Northeast } & MA & 1.96 & $1.54(79 \%)$ & $0.42(21 \%)$ \\
\hline & PI & 2.03 & $1.63(80 \%)$ & $0.40(20 \%)$ \\
\hline & $\mathrm{CE}$ & 2.13 & $1.75(82 \%)$ & $0.38(18 \%)$ \\
\hline & $\mathrm{RN}$ & 1.94 & $1.57(81 \%)$ & $0.37(19 \%)$ \\
\hline & PB & 2.15 & $1.67(78 \%)$ & $0.48(22 \%)$ \\
\hline & PE & 2.13 & $1.80(85 \%)$ & $0.33(15 \%)$ \\
\hline & $\mathrm{AL}$ & 1.83 & $1.42(78 \%)$ & $0.41(22 \%)$ \\
\hline \multirow{6}{*}{ East } & SE & 1.96 & $1.52(77 \%)$ & $0.44(23 \%)$ \\
\hline & BA & 1.89 & $1.61(85 \%)$ & $0.29(15 \%)$ \\
\hline & $\mathrm{MG}$ & 2.02 & $1.75(87 \%)$ & $0.27(13 \%)$ \\
\hline & ES & 2.04 & $1.60(79 \%)$ & $0.43(21 \%)$ \\
\hline & RJ & 2.02 & $1.79(89 \%)$ & $0.22(11 \%)$ \\
\hline & GB & 2.05 & $1.62(79 \%)$ & $0.44(21 \%)$ \\
\hline \multirow{4}{*}{ South } & SP & 2.07 & $1.83(89 \%)$ & $0.23(11 \%)$ \\
\hline & PR & 2.02 & $1.71(85 \%)$ & $0.31(15 \%)$ \\
\hline & $\mathrm{SC}$ & 2.08 & $1.73(83 \%)$ & $0.35(17 \%)$ \\
\hline & $\mathrm{RS}$ & 2.02 & $1.76(87 \%)$ & $0.26(13 \%)$ \\
\hline \multirow{2}{*}{$\begin{array}{l}\text { Center- } \\
\text { west }\end{array}$} & $\mathrm{MT}$ & 1.93 & $1.56(81 \%)$ & $0.37(19 \%)$ \\
\hline & GO & 1.87 & $1.43(76 \%)$ & $0.44(24 \%)$ \\
\hline
\end{tabular}

Notes: Regional grouping follows the 1959 census. Percentages indicated are shares of total output multiplier for each state.

Source: elaborated by the authors. 
Once again, we wish to call the attention to the larger states. As a rule, these states present an above average total output multiplier - as expected, once the total output multiplier is a multiple of the backward linkage, presented above. But, more interestingly, the seven states exhibiting a larger proportion of inside output multiplier relative to total output multiplier (RJ, SP, RS, MG, BA, PE, and PR) belong to the eight economically larger states in the country, whose output multiplying effects take place $84.5 \%$ or more within the own state. An exception, in this case, is the Federal District (GB), $16^{\text {th }}$ on the list, with inside output multiplier of $78.7 \%$. Notice these results depict not so much that the relevant economic division is the one between small and large states, but rather that it is the one between each of the large states. For they present the larger inside output multipliers, that is, the effects of a variation of demand in any of these states unfold more within each one of them, than is the case for smaller states. Of course, this reasoning is only relative. In order to decide whether, for example, an inside output multiplier larger than $88 \%$ (as is the case of SP and RJ) is 'high' in a more absolute sense, we would have to provide for relevant points of comparison, which we are unable to fix in our current framework.

Whilst the focus of this paper is the regional dimension of the Brazilian economic structure, once this is the new characteristic of the matrix we are using for our analysis, before we move on to pure linkages, we quickly present Rasmussen-Hirschman backward and forward linkages for whole sectors, because, although the original national matrix can produce a similar set of results, the linkages obtained for whole states from the inter-state matrix are expectedly different. 
Figure 2. Backward vs. Forward Linkages of Sectors

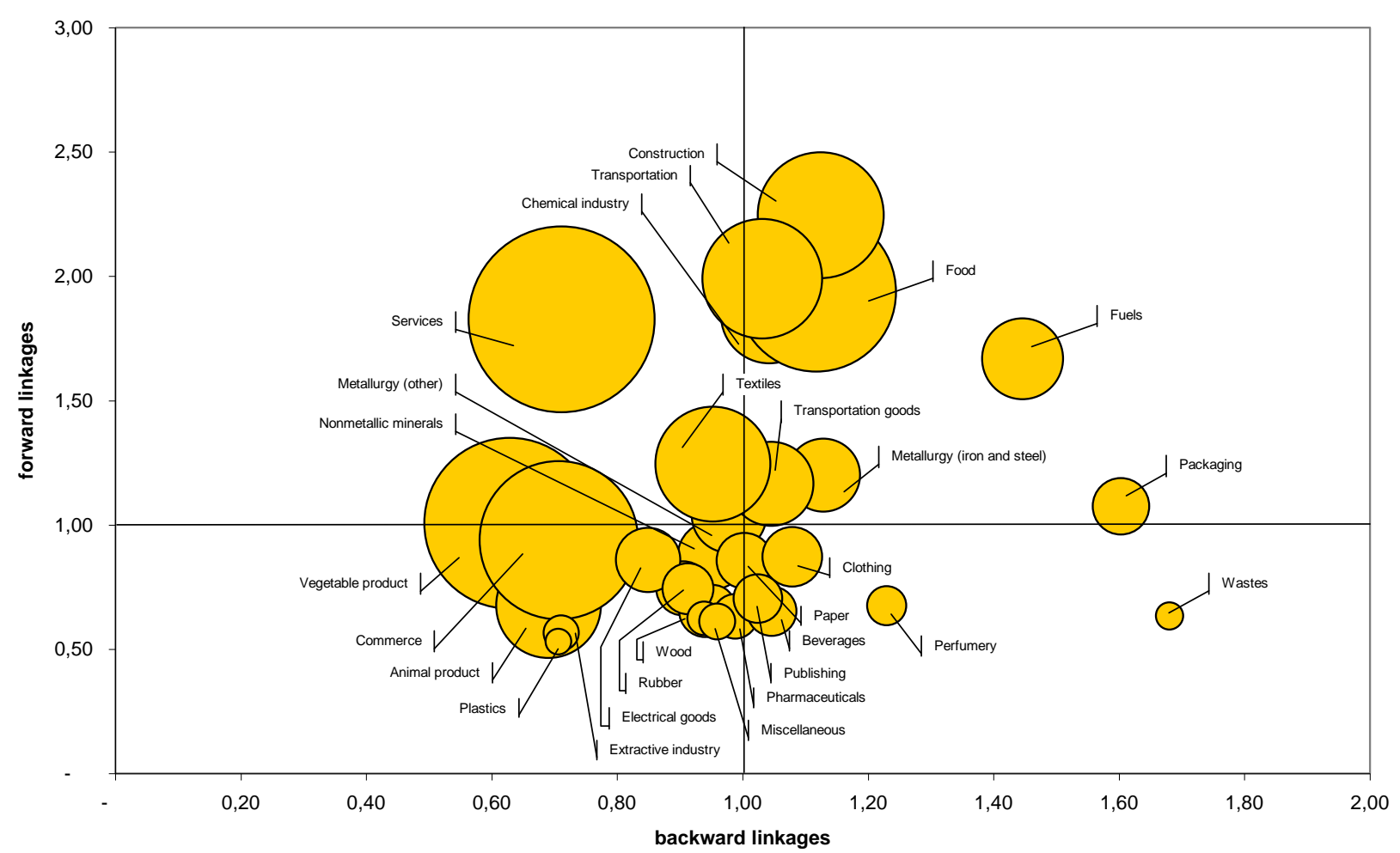

Note: Size of the bubbles represents the sectors' total output.

Source: elaborated by the authors.

Denominating key sectors as the ones which have both above average backward and forward linkages, we find in this group the sectors of fuels, packaging, construction, food, transportation, chemical industry, metallurgy of iron and steel, and transportation goods. Once again, we find the fictitious sectors with very high backward linkages, for the same reasons discussed above.

Pure linkages can provide still another perspective to the structure of the estimated inter-state input-output matrix, by emphasizing the value of output in identifying key sectors and regions, complementing the outlook rendered by cumulative Rasmussen-Hirschman linkages presented and discussed above. 
Computation of pure linkages ${ }^{13}$ is based on a partition of the matrix of technical input coefficients, $A$ :

$A=\left[\begin{array}{ll}A_{j j} & A_{j r} \\ A_{r j} & A_{r r}\end{array}\right]$

where $j$ denotes a sector, or group of sectors, of interest - in our case, a sector within a state and $r$ the remaining sectors of the matrix. Pure backward linkages (PBL) and pure forward linkages (PFL) were calculated as:

$P B L=e \Delta_{r} A_{r j} \Delta_{j} Y_{j}$

$P F L=\Delta_{j} A_{j r} \Delta_{r} Y_{r}$

where (i) $\Delta_{r} \equiv\left(I-A_{r r}\right)^{-1}$; (ii) $\Delta_{j} \equiv\left(I-A_{j j}\right)^{-1}$; (iii) $Y_{j}$ is the total output of sector $j$; and (iv) $Y_{r}$ is a $((\mathrm{N} . \mathrm{R}-1) \times 1)$ vector with the respective total outputs of the remaining sectors. Pure total linkages (PTL) were defined as the sum of PBL and PFL.

Table 3 presents ranks for the largest 25 linkages for each of the three indicators.

As expected, given the characteristic of pure linkages and results presented above, the economically larger states appear in prominence. Moreover, São Paulo clearly stands out even among the large states. It has 14 of the 25 largest PBL, 15 of the 25 largest PFL, and 16 of the 25 largest PTL.

It is also interesting to note that the profile of the sectors with the largest linkages is different between SP and the remaining states figuring on the list displayed in Table 3. For example, for PBL, while SP appears with such sectors as transportation goods, textiles, electrical goods, machine tools, among others, the remaining states are only listed with the sectors of

\footnotetext{
${ }^{13}$ For definitions in context and a wider discussion on the subject, see Guilhoto et al. 'Linkages and Multipliers in a Multiregional Framework'.
} 
food (RS, PR, MG, GB, RJ, and PE), construction (GB, MG, RJ, and GO), transportation (MG). Similarly, while SP has within the largest PTL such sectors as chemical industry, transportation goods, electrical goods, metallurgy (iron and steel) and metallurgy (other), among other sectors, the remaining states figure only with construction (GB, and MG), food (RS, PR, and MG), vegetable product (PR, MG, and RS), and services (GB). Within the PFL, the states other than SP appear in a somewhat more diversified fashion, with such sectors as metallurgy of iron and steel (RJ, and MG), services (GB, RS, and MG), and chemical industry (GB). This is per se not a statement about the diversification of each of these states economy. Nevertheless, given that these linkages were calculated and ranked according to the respective sectors' importance relative to the national economy, these results give an interesting assessment not only of the size of the economy of the state of SP within the Brazilian economy, which is a well know fact, but also of the state's structural importance. 
Table 3. Largest Backward, Forward, and Total Pure Linkages

\begin{tabular}{|c|c|c|c|}
\hline Rank & $P B L$ & $P F L$ & $P T L$ \\
\hline 1 & Food (SP) & Chemical industry (SP) & Food (SP) \\
\hline 2 & Construction (SP) & Services (SP) & Services (SP) \\
\hline 3 & Transportation goods (SP) & Vegetable product (SP) & Construction (SP) \\
\hline 4 & Textiles (SP) & Metallurgy (other) (SP) & Chemical industry (SP) \\
\hline 5 & Electrical goods (SP) & $\begin{array}{l}\text { Metal. (iron and steel) } \\
\text { (SP) }\end{array}$ & Commerce (SP) \\
\hline 6 & Commerce (SP) & Commerce (SP) & Transportation goods (SP) \\
\hline 7 & Food (RS) & Paper (SP) & Textiles (SP) \\
\hline 8 & Construction (GB) & $\begin{array}{l}\text { Metal. (iron and steel) } \\
\text { (RJ) }\end{array}$ & Vegetable product (SP) \\
\hline 9 & Machine tools (SP) & Vegetable product (PR) & Electrical goods (SP) \\
\hline 10 & Food (PR) & Vegetable product (RS) & Metallurgy (other) (SP) \\
\hline 11 & Clothing (SP) & Vegetable product (MG) & Transportation (SP) \\
\hline 12 & Construction (MG) & Textiles (SP) & Construction (GB) \\
\hline 13 & Food (MG) & $\begin{array}{l}\text { Non-metallic minerals } \\
\text { (SP) }\end{array}$ & Food (RS) \\
\hline 14 & Transportation (SP) & Fuels (SP) & Machine tools (SP) \\
\hline 15 & Services (SP) & Packaging (SP) & Construction (MG) \\
\hline 16 & Food (GB) & Animal product (SP) & Vegetable product (PR) \\
\hline 17 & Food (RJ) & Services $(\mathrm{GB})$ & Food $(\mathrm{PR})$ \\
\hline 18 & Transportation (MG) & $\begin{array}{l}\text { Metal. (iron and steel) } \\
\text { (MG) }\end{array}$ & Clothing (SP) \\
\hline 19 & Construction (RJ) & Transportation (SP) & Fuels (SP) \\
\hline 20 & Food (PE) & Chemical industry (GB) & $\begin{array}{l}\text { Metal. (iron and steel) } \\
\text { (SP) }\end{array}$ \\
\hline 21 & Furniture (SP) & Rubber (SP) & Vegetable product (MG) \\
\hline 22 & Construction (GO) & Transportation goods (SP) & Services (GB) \\
\hline 23 & Beverages (SP) & Services (RS) & Vegetable product (RS) \\
\hline 24 & Perfumery (SP) & Services (MG) & $\begin{array}{l}\text { Non-metallic minerals } \\
\text { (SP) }\end{array}$ \\
\hline 25 & Pharmaceuticals (SP) & Animal product (RS) & Food (MG) \\
\hline
\end{tabular}

Source: elaborated by the authors.

\section{Final Comments}

This paper has presented an overview of the regional economic structure of Brazil in 1959 through the estimation an inter-state input-output matrix. One of the main contributions of this paper is the estimated matrix, which thus becomes available to other researchers on request to the authors. The matrix here presented is the oldest inter-state matrix for Brazil. It can, hence, be an important tool for the study of the regional productive structure at an 
historical moment in which the regional question appeared as a central national issue. Limitations and caveats of the matrix - stemming from the original national matrix, from limited sources of data, and from the adopted estimation procedures - were pointed and discussed along the paper, and should be kept in mind, though.

We have characterized the matrix from two different perspectives. First, from a methodological point of view, we provided a minute description of sources of data, estimation procedures, and hypothesis made. The estimation was made based on Rijckeghem's (1967) national matrix for 1959 and additional data obtained from several sources, using cross-industry and location quotients.

Second, we also provided a panoramic structural portrait of the estimated matrix, through the use of selected indicators. Distinguished features of the results included the assessment of the structural importance, besides their economic size, of the larger states, particularly of São Paulo. As well as some evidence of economic introversion of each of these large states, when compared to the smaller ones.

\section{Appendix}

This appendix describes in some detail the sources of data and hypotheses assumed for the compilation of the eight matrices in the form Sector $\mathrm{X}$ State of additional (regional) information used to estimate the Inter-State Input-Output table from Rijckeghem's national table. The eight matrices comprise information on: a) the distribution by state of the (origin of) production of each sector (1); b) the distribution by state of the (origin of) value added, including gross returns to capital (2) and wages, salaries, and social security (3); c) the distribution by state of the (destiny of) final demand, including households consumption (4), government consumption (5), investment (6), exports (7), and imports (8).

Origin of production by state: the information on the 33 productive sectors came respectively from:

Sectors 1 and 2, agricultural sectors: the source of data used were the 
national accounts ${ }^{14}$, which was the same source Rijckeghem used in his estimates. It was necessary to estimate production for the states of RO, $\mathrm{AC}, \mathrm{RR}$, and AP, not reported in the national accounts. It was done proportionately to the agricultural workforce in 1959 (pessoal ocupado na agricultura) relative to the other states of the northern region, obtained from the Agricultural Census. ${ }^{15}$

$\checkmark$ Sector 3, electric energy: production by state of electric energy was estimated from data we found of consumption of electric energy, hence there is here implicit an hypothesis regarding the non-tradability between states of this product. Data on industrial consumption of electric energy (39\% of total electric energy production) by state was found in the Industrial Census. ${ }^{16}$ The remainder of the value in the national table was then distributed proportionately to the consumption of electric energy in the municipalities of the states capitals in $1959 .{ }^{17}$

$\checkmark$ Sectors 4 and 5, commerce and services: commerce by state was estimated proportionally to the commercial flux (giro comercial) of 1959, data found in the Statistical Year-Book, ${ }^{18}$ which was in turn calculated from data on sales tax's (imposto sobre vendas e consignações) collection. Services by state were also supposed to be non-tradable and were estimated from primary data or estimates of expenditures on services by state by each sector. Data on industrial expenditure on services (17\% of total service) were obtained from the Industrial Census, ${ }^{19}$ commercial expenditure on services (13\%) was obtained in the Commerce and Service

\footnotetext{
${ }^{14}$ FGV, 'Contas Nacionais', pp. 92-5.

${ }^{15}$ Brasil, Censo Agrícola de 1960, p. 26.

${ }^{16}$ Brasil, Censo Industrial de 1960, p. 119.

${ }^{17}$ IBGE, Anuário Estatístico do Brasil - 1961, p. 276.

${ }^{18}$ IBGE, Anuário Estatístico do Brasil-1961, p. 263.

${ }^{19}$ Brasil, Censo Industrial de 1960, p. 119-120.
} 
Census. $^{20}$ Expenditure on commerce of the primary, electric energy, transportation, and construction sectors (adding to 6\%) were estimated proportionately to their respective productions by state. Household expenditure on commerce $(60 \%)$ was estimated proportionately to each state's internal income in $1959 .^{21}$ Finally, the service sector selfconsumption (4\%) was estimated proportionately to the service expenditure by state of the remaining sectors.

$\checkmark$ Sectors 6 to 8, fictitious sectors: residuals for each industrial sector were distributed by state proportionately to the respective sector total production. Fuel and packaging productions were also supplied indirectly from data and estimates on expenditures. This implies we are making here that same hypothesis on non-tradability, but which is especially cumbersome in the case of these sectors. But we couldn't avoid it, this is a consequence of Rijckeghem's decision to work with these sectors. The only reasonable sources of information to be found on them were the Censuses, and fuel and packaging were accounted there within the cost structure. Therefore, care is to be taken in any conclusion of regional character regarding these sectors. Industrial expenditure on fuels $(28 \%$ of total fuel production) by state was obtained in the Industrial Census. ${ }^{22}$ Expenditure on fuels of the primary, electric energy, commerce, services, transportation, and construction sectors (adding to 56\%) were estimated proportionately to their respective productions by state. Government fuel consumption (4\%) was estimated proportionately to public employees by state. ${ }^{23}$ Household fuel consumption $(11 \%)$ was estimated proportionately to each state's internal income in $1959 .{ }^{24}$ Export fuel consumption $(0.1 \%)$

\footnotetext{
${ }^{20}$ Brasil, Censos Comercial e dos Serviços de 1960, p. 67.

${ }^{21}$ IBGE, Anuário Estatístico do Brasil-1961, p. 269.

${ }^{22}$ Brasil, Censo Industrial de 1960, p. 119.

${ }^{23}$ Brasil, Censo Demográfico de 1960, p. 101.

${ }^{24}$ IBGE, Anuário Estatístico do Brasil-1961, p. 269.
} 
was supposed proportional to exported tonnage in $1959 .{ }^{25}$ Industrial expenditures on packaging ( $92 \%$ of total packaging production) data were obtained in the Industrial Census. ${ }^{26}$ The vegetable product sector packaging expenditure (8\%) was estimated proportionally to its production by state.

Sectors 9 to 31, industrial sectors: data on the production by state of the industrial sectors were the best we were able to obtain, and this is crucial given the importance of these sectors for several purposes in inputoutput analyses. Indeed, the information is not only fully compatible with the one used by Rijckeghem for the national matrix, but it was also his and ours best quality data. It is to be found in the Industrial Census. ${ }^{27}$

$\checkmark$ Sectors 11 and 12, metallurgical sectors: data on the disaggregated metallurgical sectors by state was not readily available in the National Series of the Industrial Census though. In order to reconstruct them we used two special publications of the Industrial Census. A minute classification of industries which served as norm to the tabular presentation of the results of the Industrial Census of $1960^{28}$ allowed us to produce a list of products for the sector 'metallurgical (iron and steel)' consistent with the original aggregated data, which included 'Steel products - iron and steel', 'Steel products - alloys', and part of 'Various metallurgical products'. The production by state of each product on this list was then found in the Special Series of the Industrial Census. ${ }^{29}$ The 'metallurgical (other)' sector was then calculated as residual from the

${ }^{25}$ IBGE, Anuário Estatístico do Brasil - 1961, p. 220.

${ }^{26}$ Brasil, Censo Industrial de 1960, p. 119.

${ }^{27}$ Brasil, Censo Industrial de 1960, pp. 92-114.

${ }^{28}$ Instituto Brasileiro de Geografia e Estatística (IBGE), Serviço Nacional de Recenseamento. Classificação de indústrias: Produtos - Matérias-primas (Rio de Janeiro: IBGE, 1963).

${ }^{29}$ [Brasil], Censo Industrial de 1960: Matérias-primas e produtos, passim. 
aggregated metallurgical sector. ${ }^{30}$

$\checkmark$ Sectors 32 and 33, construction and transportation: the construction sector production by state was estimated as proportional to consumption of cement in $1959 .{ }^{31}$ The transportation sector production was estimated from information or estimates on transportation expenditure by state for several sectors. Expenditures on transportation of the industrial sectors and of the commercial sector (adding to $17 \%$ of total transportation) are found in the respective censuses. ${ }^{32}$ Households expenditures on transportation $(54 \%)$ by state were supposed proportional to total population of each state. ${ }^{33}$ Expenditure on transportation of the Construction and Services sectors (adding to 3\%) were supposed to be proportional to their respective productions. Export sector expenditure on transportation (8\%) was supposed proportional to exported tonnage in 1959. ${ }^{34}$ Government expenditure on transportation (16\%) was supposed to consist of subsidies, and was, hence, distributed by states proportionately to the sum of above mentioned transport expenditures. Transportation self-consumption (2\%) was supposed proportional to the remaining sectors expenditures on transportation.

Origin of value added by state: Data on Wages and salaries for the industrial sectors were obtained in the Industrial Census. ${ }^{35}$ Social Security (plus indemnification) expenses by state of all the industrial sectors (aggregated) are informed in the Industrial Census, ${ }^{36}$ the distribution between sectors of this total by state was done proportionately to the wages and salaries paid by each sector in the state. Wages, salaries and social security of the industrial sectors add to $25 \%$ of total WSSS. Data on wages, salaries and social security paid by the

\footnotetext{
${ }^{30}$ Brasil, Censo Industrial de 1960, p. 95.

${ }^{31}$ IBGE, Anuário Estatístico do Brasil-1961, pp. 277-78.

${ }^{32}$ Brasil, Censo Industrial de 1960, p. 120; Censos Comercial e dos Serviços de 1960, p. 67.

${ }^{33}$ Brasil, Censo Demográfico de 1960, p. 80.

${ }^{34}$ IBGE, Anuário Estatístico do Brasil - 1961, p. 220.

${ }^{35}$ Brasil, Censo Industrial de 1960, pp. 92-114.

${ }^{36}$ Brasil, Censo Industrial de 1960, p. 120.
} 
commercial sector $(8 \%)$ is available in the Commercial Census. ${ }^{37}$ Wages, salaries and social security paid by the government $(16 \%)$ were supposed to be proportional to the number of public employees by state, ${ }^{38}$ and those paid by households (7\%) were assumed to be proportional to the internal income by state. ${ }^{39}$ Wages, salaries and social security from the remaining sectors (adding to $44 \%$ ) were assumed to be proportional to their respective production by state. To estimate Gross returns to capital of the industrial sectors (adding to $30 \%$ of total GRC) we initially estimated Value added by state (but aggregated for sectors) from data available in the Industrial Census. ${ }^{40}$ This was then distributed, within each state, trough sectors proportionately to the Value of Industrial Transformation, found in the Industrial Census. ${ }^{41}$ This resulted in an estimate for Value Added by sector and by state. Gross returns to capital of the industrial sectors were finally obtained subtracting from this Value Added the respective Wages, salaries and social security we had already estimated. Gross returns to capital of the remaining sectors $(70 \%)$ were assumed to be proportional to their respective production by state.

Destiny of final demand by state: Household consumption of each sector's production was distributed proportionally to internal income by state. Government consumption was distributed proportionally to the number of public employees by state. Investment expenses for each sector were estimated proportionally to Gross returns to capital by state for the respective sector. Total exports by state were assumed to be equal to exports trough ports and airports, data found in the Statistical Year-Book. ${ }^{42}$ Exports for each sector within each state were distributed proportionately to the respective state's production by sector. Total exports by sector were then distributed through the states proportionately to the quantities thus obtained. An identical procedure was followed for imports, but based on data on imports trough ports and airports found in the Statistical Year-Book. ${ }^{43}$

\footnotetext{
${ }^{37}$ Brasil, Censos Comercial e dos Serviços de 1960, pp. 64, 67.

${ }^{38}$ Brasil, Censo Demográfico de 1960, p. 101.

${ }^{39}$ IBGE, Anuário Estatístico do Brasil - 1961, p. 269.

${ }^{40}$ Brasil, Censo Industrial de 1960, pp. 119-120.

${ }^{41}$ Brasil, Censo Industrial de 1960, pp. 92-114.

${ }^{42}$ IBGE, Anuário Estatístico do Brasil - 1961, p. 220.

${ }^{43}$ IBGE, Anuário Estatístico do Brasil-1961, p. 220.
} 